\title{
The impact of e-commerce drivers on e-customer loyalty: Evidence from KSA
}

\begin{abstract}
Sura Al-Ayed ${ }^{a^{*}}$
${ }^{a}$ Associate Professor of Business Administration, Faculty of Business Studies, Arab Open University, Riyadh, Saudi Arabia

\section{H R O N I C L E}

Article history:

Received: June 20, 2021

Received in revised format: July

28, 2021

Accepted: October 4, 2021

Available online: October 4, 2021

Keywords:

E-commerce

E-commerce Drivers

Customer loyalty

E-customer loyalty

E-customer satisfaction

\section{A B S T R A C T}

E-commerce and online shopping is the future of global trade, hence the importance of building Ecustomer loyalty and maintaining it in the electronic markets becomes even more important. This paper attempts to identify factors affecting the value of electronic commerce in the Saudi environment. Likewise, it explores the impact of these factors on E- customer loyalty. Simple random sampling was used for the purposes of the current study, as the first study included 247 electronic customers. Data were collected through electronic questionnaires sent to the study participants. The results show that the factors had a positive impact in building E- customer loyalty Care, Character, Choice, Convenience, Customization, and Cultivation. Basically, e-commerce is considered a pioneer in business organizations today, and this is witnessed by its increasing and growing profits and expanding its market share, through its focus on the E-loyalty customers. Basically, e-commerce is considered a pioneer in business organizations today, and this is witnessed by its increasing and growing profits and expanding its market share, through its focus on the E-loyalty customers.
\end{abstract}

\section{Introduction}

Recently, the world has witnessed an increasing interest in electronic commerce as an inevitable and necessary consequence of recent developments in the field of information and communication technologies. There has been a significant shift from the traditional form of trade to the modern electronic form, electronic commerce has become a tangible reality in the current environment, and many countries are seeking to maximize the role of electronic commerce, especially considering the changing world. New challenges are expected to be magnified because of its role soon to the impact of this trade on the markets and the performance of enterprises and their competitiveness, where e-commerce is expected to be the dominant method of trade between the organizations and individuals during this century all over the world. E-commerce is a feature of the knowledge-based economy, and it is one of the most important applications of information and communication technology (ICT), which countries should pay attention to keep pace with the modern environment and the developments imposed by their representative in the growing interest in e-commerce. E-commerce has been linked to the concept of e-customer, which relies primarily on e-commerce applications to meet its needs and desires. As a result, the importance of research is embodied in the researchers' attempt to determine the nature, characteristics, applications, and impact of E-commerce on customer loyalty. Studies show that many E-customers tend to be more loyal than traditional consumers if they feel the service provided is of high quality (Reichheld \& Schefter, 2000; Devaraj et al., 2003). Consumer satisfaction with online shopping is associated with factors such as entertainment, speed, quality of information and reliability (Kim \& Lim, 2001). Thus, a successful Ecommerce strategy must ensure that customers receive the value they expect to ensure their future return. Moreover, the cost of acquiring and retaining customers greatly reduces every transaction (Porter, 2001). Thus, the most important aspect in

* Corresponding author.

E-mail address: $\underline{\text { s.alayed } @ \text { arabou.edu.sa }(\text { S. Al-Ayed) }}$

(C) 2022 by the authors; licensee Growing Science, Canada. doi: $10.5267 /$ j.ijdns.2021.10.002 
determining a successful Internet strategy is to create resilience as well as awareness for the e-customer while knowing that future success depends on being able to change focus and / or adjust the strategy for future business needs (Guah, 2006).

\section{Theoretical framework}

\subsection{Theoretical foundation}

We can support our reasoning on two theories namely: Theory of reasoned action (TRA) and Expectation-confirmed theory (ECT). To understand the behavioral intention Fishbein and Ajzen (1975) introduced the theory of reasoned action. Theory of Reasoned Action (TRA) is the most important determinant of behavior, namely behavioral intention. According to TRA, the direct determinant of individual behavioral intentions is their attitude to behavior and subjective norms related to behavior. Attitudes are determined by individual beliefs about the results or attributes of conducting a behavior (beliefs in behavior), weighted by the evaluation of those results or attributes. Thus, someone who holds a strong belief that the results that are considered positive will result from carrying out the behavior in question will have a positive attitude towards the behavior. Conversely, someone who holds a strong belief that negative valued results will result from behavior will have a negative attitude. Likewise, a person's subjective norms are determined by his normative beliefs: that is, whether an important reference individual approves or disapproves of doing behavior, weighed by one's motivation to obey the reference. Someone who believes that a particular reference thinks that he or she must conduct behavior and who is motivated to meet their expectations will have positive subjective norms. Conversely, people who believe in this referent think that they should not conduct behavior will have negative subjective norms, and people who are less motivated to comply with these references will have relatively neutral subjective norms. The essence of TRA is the assumption that the most important direct determinant of behavior is behavioral intention. The success of theories in explaining behavior depends on the extent to which certain behaviors are under the control of the will, that is, individuals can exert great control over behavior (Glanz et al., 2015). The TRA formulation is after trying to estimate the differences that exist between attitudes and behavior. The basics of TRA come from the field of social psychology. Social psychologists try, among other things, to explain how and why attitudes influence behavior, which is also very important in reflecting this research namely, how and why people's beliefs change the way they act. This study will look at how attitudes and beliefs affect cell phone money usage. Behavior can be verbal or non-verbal. TRA proposes three general constructs, namely: (1) behavioral intention, (2) attitude, and (3) subjective norms (Otieno et al., 2016). Applying a parsimonious version of the TRA McKnight et al. (2002) elaborated a multidimensional model of trust in e-commerce. Authors found that consumers hesitate to transact via web because of uncertainty about vendor behavior or a perceived risk of having stolen personal information by hackers. Consequently, trusting beliefs (perceptions of specific Web vendor attributes) lead to trusting intentions, which in turn influence trust related behaviors. Expectation-confirmed theory (ECT) has been widely used to study the consumer satisfaction and post purchase behaviors, repurchase (loyalty) (Oliver 1999) and their antecedents (Bhattacherjee, 2001; Demangeot \& Broderick, 2007).

The ECT is widely used in marketing literature and become very popular in other scientific fields. In fact, a process by which consumers achieve repurchase intentions within the ECT framework can be described as follows (Oliver, 1999): First, consumers form initial expectations of certain products or services before being purchased. Second, they accept and use that product or service, and after a period of consumption, they form their perceptions around its performance. Third, they rate performance taking into consideration their initial expectations and determine the degree where their expectations were confirmed. Fourth, they form satisfaction, or influence, based on the level of confirmation and the expectations of those who become basis for the confirmation. Finally, satisfied consumers form intentions repurchases, while unsatisfied users do not continue subsequent use. Therefore, ECT consists of five components: expectations, perceived performance, confirmation, satisfaction and reparative intentions. Consumers form a reasonable perception about the performance of certain services when they really use it. Positive or negative disconfirmation level formed when expectations before and after purchase compared to which in turn affect the overall satisfaction of a product or services (Pokryshkina, 2015). This interaction proposed by ECT shows that initial expectations consumers of products, services or technological artifacts, creating a framework reference, or initial reference point, which then allows them to make a comparative assessment after purchase or adoption. This theory states that when the performance of a product, service or technological artifact is lower than as expected, comparative assessment falls below the initial terms of reference and generate negative disconfirmation. This negative confirmation causes dissatisfaction (Ferreira, 2016).

\subsection{E-customer loyalty}

The loyalty concept has received a great attention by marketing studies (Chiou, 2004; Lin \& Wang, 2006; Flavian et al., 2006; Rauyruen \& Miller, 2007). Even though the rich studies dealing with loyalty, many definitions were proposed to this concept. The literature review suggests that there are two major approaches, namely, behavioral, and attitudinal, that can measure customer loyalty (Piha \& Avlonitis, 2015; Kandampully et al., 2015). Behavioral loyalty refers to customer attitudes toward repurchasing a particular brand due to their liking (Cyr, 2008; Jiang et al., 2015). In this sense, Oliver (1999) defines customer loyalty as a deep commitment, over time, to repurchase a favorite or a potential product or service despite the marketing temptation presented by the competitors that are susceptible to causing a switching behavior. According to Oliver (1999), loyalty is a multi-sequence process: it begins with cognitively (aspects related to the performance of the brand), second affectively (likeability of the brand), third cognitive loyalty (repurchase) and finally action (commitment to repurchase). Although 
this approach offers a measure of a complex concept, it does not differentiate between true loyalty and spurious loyalty. In fact, a consumer can repurchase constantly the usage of a given brand (behavioral loyalty), but at the same time, threats to loyalty can arise in each sequence mentioned later, like performance deterioration, looking for variety (Spurious loyalty). In response to criticisms addressed to behavioral approach, researchers have proposed the attitudinal approach. It consists of an emotional and psychological state (true loyalty) to commit back the purchase and to recommend to other consumers (Wong $\&$ Zhou, 2006). In this sense, it is a great challenge to any type of business to identify and understand the determinants that will have an impact on customer loyalty. In the context of E-Commerce, E-customer loyalty is a very important and valuable dimension. Traders who use E-commerce try to build customer loyalty through websites. E-business as opposed to traditional one offers great flexibility, a large market coverage, lower customers' structures, rapid transactions, broad line products, convenience and customization. In fact, companies are aware of the growing role of E-business in creating new wealth, which leads them to focus on the establishment of E-customer loyalty. The Internet for these decades has created a hyper-competitivity where transaction costs are low and a flexibility for customers to move from one website to another. This situation creates a perfect market with concurrence based particularly on price, which reduces the stickiness of E-customer loyalty. Moreover, loyal customers will be the main drivers of information to themselves and to other customers. Customer trust, satisfaction and beliefs are the main factors that can affect loyalty and will contribute to intensify the relation between the Eservice provider and the customer. In the same vein, Sambandam and Lord (1995) note that loyal E-customer can pay more and give a positive word of mouth (WOM). Srinvasan et al. (2002) indicate that E-businesses must identify and understand E-customer loyalty to gain a competitive advantage in devising strategies and increase E-customer loyalty. The authors interview 42 participants and propose $8 \mathrm{Cs}$ of the antecedents of E-customer loyalty: customization, contact interactivity, cultivation, care, community, choice, convenience, and character for continuous measurement of e-customer perception and management of E-customer service at an acceptable level. In the same vein, Dotan (2002) identifies 10 factors that are susceptible to influence online customer satisfaction: quality of product/service, service and support, value for money, speed, privacy and security, availability, access to information, predictability, and reliability. So, understanding the relationship between E-commerce drivers and E-customer loyalty represents an important opportunity to advance research in E-commerce. In the Saudi context, Eid (2011) shows that satisfaction and belief have a positive and significant effect on E-customer loyalty. The study by Kassim and Ismail (2009) and Kassim and Abdullah (2010), concerning online customers, found that the improvement in satisfaction and confidence improves customer loyalty.

\subsection{The effect of E-commerce drivers on E-loyalty}

The question of customer retention is very important in E- commerce. Customer loyalty is tightly associated with customer willingness to pursue in the relationship (Lee et al., 2001; Wangenheim, 2003; Jones et al., 2000; Caruana, 2004). Consequently, E-com companies need to develop a thorough understanding of the antecedents of E-loyalty to attain customer retention. Nevertheless, customer-switching behavior has a direct and strong effect on E-Loyalty. In fact, the barriers to customer switching are lower compared to traditional companies. The barriers to customer switching are the consumer perceptions of money, time and efforts related with changing from one site to another. These factors can increase the dependence on an exciting provider (Morgan \& Hunt, 1994). In addition, companies should take into consideration that these days acquiring a new customer will be much higher than the cost of maintaining an old one because it leads to long-term profitability. Many studies assert that online customers prefer to shop on websites perceived as having a high-quality interface. Adamic and Huberman (2001), in a study showing the online shopping behavior confirm that the top $1 \%$ websites capture about $50 \%$ of web traffic, which indicates that shoppers focus their search for just a few popular websites. Additionally, trust concept is interrelated to loyalty; it is an important catalyst in transaction relationships. In marketing literature, in the commitment-trust relationship, trust constitutes an essential component in a transaction relationship when one party has confidence regarding the integrity and reliability of the other partner (Morgan \& Hunt, 1994; Ranaweera \& Phrabu, 2003). Indeed, trust can be conceptualized as a "technology acceptance model" could be a determinant component to attract and influence the user's willingness to engage in online transactions and personal sensitive information (Friedman et al., 2000; Wang et al., 2003).

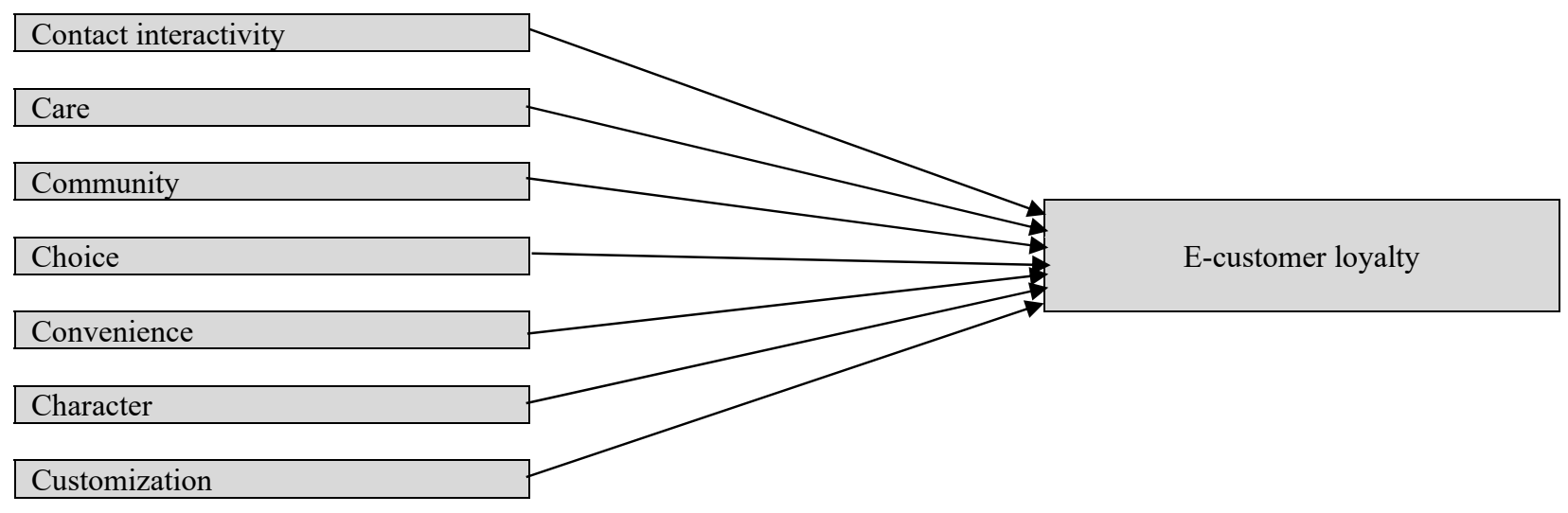

Fig.1. Research Model (adopted from Srinivasan’ (2004) 
These factors are based on the consequences and impact behind the different motives and feelings of electronic customers. This helps to understand management scenarios because they can define strategic decision-making (Khatri and $\mathrm{Ng}$, 2000). These factors have been divided into eight different categories, known as "eighth customer services", which aim to influence the customer's tendency towards e-commerce products and services to obtain a positive trend.

\section{Methodology}

\subsection{Data collection}

This study adopted the survey method to suit it to describe the characteristics of many electronic customers, the flexibility in data collection, and the ability to provide participants with more explicit and accurate answers. In addition, this study used the survey method because its aim was to generalize the results of the sample to all electronic customers. The population of this study consists of all electronic clients in the Kingdom of Saudi Arabia. Based on the Krejcie and Morgan schedule in order to determine the appropriate sample size, the 382-sample size was necessary to represent a cross section of this population (Sekaran \& Bougie, 2016). A simple random sample consisted of electronic customers who used electronic applications and stores in shopping operations. Data collected over 21 weeks. Scientific research ethics were adhered to in collecting data in terms of (confidentiality, anonymity, and volunteering). Data were collected from 450 electronic customers, and invalid questionnaires were excluded due to incomplete answers. The number of valid questionnaires for analysis 247 became electronic customer. Fig. 2 presents the demographic characteristics of the Sample individuals.

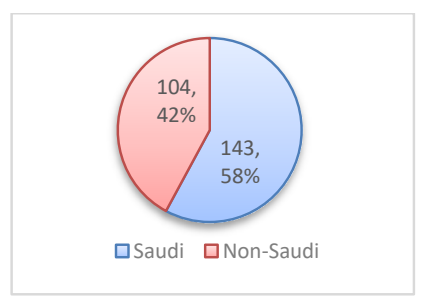

Nationality

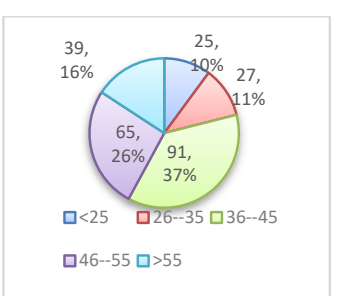

Age

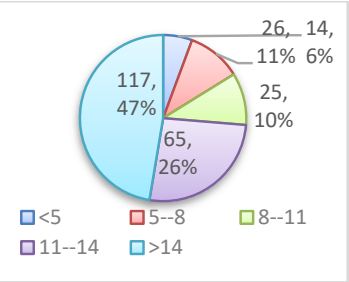

Income $(\times 1000$ Rials $)$

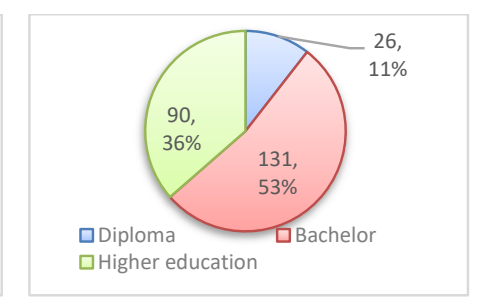

Qualification

Fig. 2. Demographic characteristics of the Sample individuals

The results of demographic characteristics of the sample individuals, as shown in Table 1, that one third of the respondents were from the age (36-45) years (36.8\%), (46-55) years (26.3\%), (More than 56) years (15.8\%), and (26-35) years (11.1\%), followed by those the respondents were under 26 years of age (10\%). In terms of the participants' nationality, it was noted that most of them were Saudi (57.9\%), while the respondents were non-Saudi (42.1\%). Regarding the income level, the highest $(47.4 \%)$ of respondents had a high-income level (More than 14000), while (5.8\%) had a low-income level (less than 5000 SR). About half of the sample individuals (53.2\%) have a Bachelor qualification, and some respondents $(36.3 \%)$ have a higher education qualification and rest $(10.5 \%)$ have a Diploma qualification.

\subsection{The Saudi context}

The KSA is the largest and youngest country among The Gulf Cooperation Council. In fact, $45 \%$ of the Saudi population is under the age of $24 \%$, which influenced the nature of the economic transactions. KSA counts 21.6 million of E-commerce users by the end of year 2018, and they estimate that they will be 23.1 million of users by the end of year 2022. Saudi Arabia also held the greatest mobile market in the region. It is confirmed that the country has the biggest and fastest growth of Information and Communication (ICT) marketplace in the GCC. In 2017, the United Nations Conference on Trade and Development (UNCTAD) presented a global study to understand countries' willingness to engage in online trade. The study assessed countries based on four criteria for a unified outcome. These four criteria are the use of the Internet, secure servers per million people, penetration of banks and mail reliability, all of which are fundamental to the growth of e-commerce within the country. According to the report, Saudi Arabia ranks 46th out of 144 countries, with a score of 69 . It is equal to countries such as Italy and Russia, which are higher than some major economies such as India and China. In comparison between 2009 and 2016 for Saudi Arabia, the report shows good improvements especially in the areas of Internet use and postal reliability. Internet penetration has improved from 64 to 74, and mail reliability has improved from 69 to 75. Saudi Arabia can move to the top of the rankings by increasing the penetration of banks and credit cards and improving the number of secure Internet servers per million people.

\subsection{Variables definition}

The study relied on eight factors related to electronic commerce that affect E-customer loyalty. These factors can be explained procedurally as follows:

1- Contact interactivity: defined as the degree to which a website facilitates the interactivity with customers. The customer interface substitutes the salesperson for traditional firms. It is a determinant factor for consumers that influences the desire to return to the website (Al-Tit et al., 2020; Chang \& Chen, 2009). 
2- Care: Customer service refers to the attention paid to the interface toward the consumer before and after the act of purchase to maintain long-term relationships.

3- Community: a community can be assimilated to a social media entity. It is composed by the actual and potential consumers; the e retailers organize and manage the technical atmosphere to facilitate the exchange of pertinent information and opinions regarding the different products/services available.

4- Choice: compared to traditional retailers, e-com companies are typically able to offer to their clients a larger range of products/services. Also, the e-retailers generally form alliances with other e-retailers to provide their customers with a large choice.

5- Convenience: it constitutes the facility to navigate into a website. In fact, about two thirds of transactions via the web are not completed because of the non-availability of information that can help the shoppers to complete their purchase quickly.

6- Character: it is the general atmosphere or personality that the web page of the online store projects to consumers, the simplicity of the visual content. which can influence the enjoyment of the shopping experience and instill a feeling of trust towards the online store.

7- Customization: it is defined as the ability of a web store to adopt products/services and transactional environments according to the aims of each individual customer, which make the web site more attractive.

6- Character: it is the general atmosphere or personality that the web page of the online store projects to consumers, the simplicity of the visual content. which can influence the enjoyment of the shopping experience and instill a feeling of trust towards the online store.

7- Customization: it is defined as the ability of a web store to adopt products/services and transactional environments according to the aims of each individual customer, which make the web site more attractive.

\subsection{Validity and reliability}

Validity and reliability of the instrument was assessed according to standardized factor loadings (SFL $>0.50$ ), Cronbach's alpha $(\alpha>0.70)$, composite reliability (CR $>0.70)$, and average variance extracted (AVE $>0.50)$ were found to be acceptable (Al-Ayed, 2019, Huang et al., 2019; Al-Tit et al., 2019, 2020; Al-Tit, 2016). The results in Table 2 pointed out that validity and statistics reliability were acceptable after drop all items of the cultivation variable, and some items of the other variables (Cont5, Care3, Com2, Choice1, Choice2, Conv1, Conv3, Char4, and E-Loy4).

Table 1

Results of reliability and validity

\begin{tabular}{|c|c|c|c|c|c|}
\hline Variables & Items & standardized factor loadings (SFL) & Cronbach's Alpha & Composite Reliability & Average Variance Extracted (AVE) \\
\hline \multirow[t]{4}{*}{ Care } & Care1 & 0.783 & \multirow[t]{4}{*}{0.767} & \multirow[t]{4}{*}{0.848} & \multirow[t]{4}{*}{0.586} \\
\hline & Care2 & 0.688 & & & \\
\hline & Care4 & 0.677 & & & \\
\hline & Care5 & 0.894 & & & \\
\hline \multirow[t]{3}{*}{ Character } & Char1 & 0.910 & \multirow[t]{3}{*}{0.843} & \multirow[t]{3}{*}{0.902} & \multirow[t]{3}{*}{0.755} \\
\hline & Char2 & 0.801 & & & \\
\hline & Char3 & 0.891 & & & \\
\hline \multirow[t]{2}{*}{ Choice } & Choice3 & 0.971 & \multirow[t]{2}{*}{0.954} & \multirow[t]{2}{*}{0.977} & \multirow[t]{2}{*}{0.956} \\
\hline & Choice4 & 0.984 & & & \\
\hline \multirow[t]{4}{*}{ Community } & Com1 & 0.714 & \multirow[t]{4}{*}{0.789} & \multirow[t]{4}{*}{0.867} & \multirow[t]{4}{*}{0.624} \\
\hline & Com3 & 0.839 & & & \\
\hline & Com4 & 0.930 & & & \\
\hline & Com5 & 0.646 & & & \\
\hline \multirow{4}{*}{$\begin{array}{l}\text { Contact Inter- } \\
\text { activity }\end{array}$} & Cont1 & 0.927 & \multirow[t]{4}{*}{0.843} & \multirow[t]{4}{*}{0.899} & \multirow[t]{4}{*}{0.700} \\
\hline & Cont2 & 0.957 & & & \\
\hline & Cont3 & 0.489 & & & \\
\hline & Cont4 & 0.886 & & & \\
\hline \multirow[t]{3}{*}{ Convenience } & Conv2 & 0.824 & \multirow[t]{3}{*}{0.802} & \multirow[t]{3}{*}{0.880} & \multirow[t]{3}{*}{0.710} \\
\hline & Conv4 & 0.857 & & & \\
\hline & Conv5 & 0.847 & & & \\
\hline \multirow[t]{5}{*}{ Customization } & Cust1 & 0.958 & \multirow[t]{5}{*}{0.905} & \multirow[t]{5}{*}{0.922} & \multirow[t]{5}{*}{0.711} \\
\hline & Cust2 & 0.910 & & & \\
\hline & Cust3 & 0.881 & & & \\
\hline & Cust4 & 0.875 & & & \\
\hline & Cust5 & 0.516 & & & \\
\hline \multirow[t]{5}{*}{ E-Loyalty } & E-Loy1 & 0.821 & \multirow[t]{5}{*}{0.810} & \multirow[t]{5}{*}{0.866} & 0.566 \\
\hline & E-Loy2 & 0.787 & & & \\
\hline & E-Loy3 & 0.708 & & & \\
\hline & E-Loy5 & 0.754 & & & \\
\hline & E-Loy6 & 0.682 & & & \\
\hline
\end{tabular}

The Pearson's correlation coefficients in Table 2 indicate that all the study variables are associated with each other. There are significant relationships between ten factors and e-loyalty, these refer to construct validity. 
Table 2

Intercorrelation of variable

\begin{tabular}{|c|c|c|c|c|c|c|c|c|}
\hline & Care & Character & Choice & Community & Contact Interactivity & Convenience & Customization & Design \\
\hline Care & - & & & & & & & \\
\hline Character & 0.595 & - & & & & & & \\
\hline Choice & 0.037 & -0.037 & - & & & & & \\
\hline Community & 0.651 & 0.466 & 0.045 & - & & & & \\
\hline Contact Interactivity & 0.863 & 0.545 & 0.330 & 0.495 & - & & & \\
\hline Convenience & 0.671 & 0.774 & 0.017 & 0.414 & 0.655 & - & & \\
\hline Customization & 0.595 & 0.592 & -0.125 & 0.534 & 0.520 & 0.772 & - & \\
\hline Design & 0.727 & 0.778 & 0.057 & 0.366 & 0.769 & 0.692 & 0.606 & - \\
\hline E-Loyalty & 0.754 & 0.660 & 0.297 & 0.591 & 0.759 & 0.466 & 0.321 & 0.676 \\
\hline
\end{tabular}

\subsection{Research conceptual model}

Figure 3 presents the conceptual model used in this research. The figure portrayed ten latent variables related to e-loyalty linked via 10 hypotheses. Care (H1), Character (H2), Choice (H3), Community (H4), Contact Interactivity (H5), Convenience (H6), and Customization (H7).

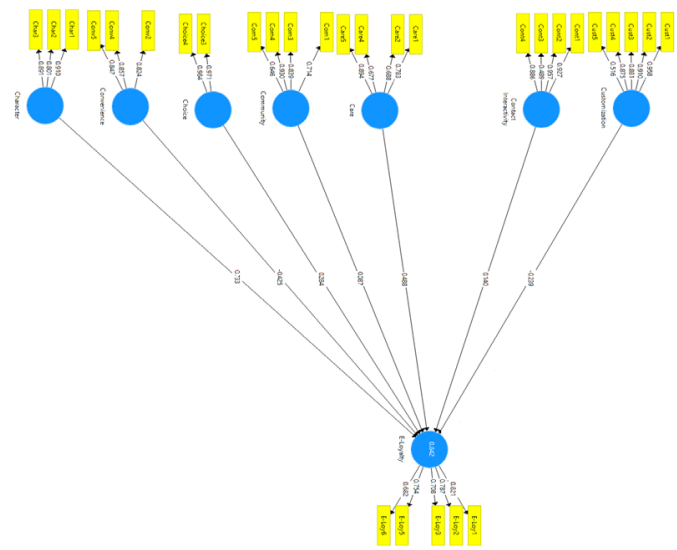

Fig. 3. Research conceptual model

\subsection{Hypotheses testing}

The results of hypotheses testing, as shown in Table 3 , indicated that the effect of care on e-loyalty was also supported ( $(=$ 0.488). Similarly, Character $(\beta=0.733)$, Choice $(\beta=0.284)$, Convenience $(\beta=0.425)$, and Customization $(\beta=0.239)$, had significant effects on e-loyalty. These findings confirmed that H1-3, H6-7 were accepted. Moreover, the results indicate that there are no significant effects of Community, and Contact Interactivity on e-loyalty, these findings confirmed that H4-5, H10 were rejected.

Table 4

Results of hypotheses testing

\begin{tabular}{llcc}
\hline \multicolumn{3}{c}{ Hypotheses } & Coefficients \\
\hline $\mathrm{H}_{1}$ & Care $\rightarrow$ E-Loyalty & $0.488^{*}$ & Supported \\
$\mathrm{H}_{2}$ & Character $\rightarrow$ E-Loyalty & $0.733^{*}$ & Supported \\
$\mathrm{H}_{3}$ & Choice $\rightarrow$ E-Loyalty & $0.284^{*}$ & Supported \\
$\mathrm{H}_{4}$ & Community $\rightarrow$ E-Loyalty & 0.087 & Not supported \\
$\mathrm{H}_{5}$ & Contact Interactivity $\rightarrow \quad$ E-Loyalty & 0.140 & Not supported \\
$\mathrm{H}_{6}$ & Convenience $\rightarrow \quad$ E-Loyalty & $-0.425^{*}$ & Supported \\
$\mathrm{H}_{7}$ & Customization $\rightarrow \quad$ E-Loyalty & $-0.239^{*}$ & Supported \\
\hline
\end{tabular}

$*(\mathrm{P}<0.05)$ Adjusted R-Square $=0.835$

\section{Discussion and conclusion}

This research aims to investigate the impact of e-commerce drivers on e-customer loyalty. The results highlighted seven drivers of e-commerce, which were care, character, choice, convenience, customization, and information content. The factors studied in this research as e-commerce drivers were chosen for related studies, therefore, numerous studies found similar results. Based on the study of Srinivasan et al. (2002), with regard to the influences that determine the factors of electronic loyalty to customers, it was found that the internal factors of the organization such as Design and Care are affected by the ethics of electronic commerce, the quality of information, customer confidence, the quality of the user interface, and customer satisfaction, and it is one of the most important effects that increase the loyalty of electronic customers. He concluded that electronic customer loyalty depends on a set of electronic options such as personalization, interaction with contacts, agriculture, sponsorship, community, choice and personality. This is consistent with our study. Factors that have been confirmed in the current study, have been confirmed by previous studies and include values in the perceived e-commerce (Ghobakhloo et 
al., 2011), Employee Knowledge of E-Commerce (Van Huy et al., 2012; Zaied, 2012), the expected ease of use of e-commerce and e-commerce applications, the comparative advantage of e-commerce, the perceived compatibility of e-commerce, the security of e-commerce, and support for senior management (Arshad et al., 2018), internet access (Ekanem \& Abiade, 2018; Scupola, 2009), as well as the perceived benefit of email - commerce (Hussain et al., 2019). Awa et al. (2015), based on the theoretical framework presented by a study on e-commerce of Tornatzky and Fleischer (1990), it was found that technological factors have a significant impact, as well as regulatory factors, and environmental factors are among the most important key factors for the adoption of e-commerce. In their agreement, this corresponds to the current study that regulatory factors such as Customization, and environmental factors such as Convenience greatly influence the adoption of e-commerce. Eid (2011) explained that electronic customer loyalty is strongly affected by customer satisfaction compared to customer confidence, especially in terms of privacy. Some studies also concluded that there is a positive impact of e-commerce ethics on loyalty to e-customers. On the other hand, there are results that were not consistent with the results of the current study and the fact that, contrary to our findings, some factors such as the technology used did not have an impact on the adoption of e-commerce (Ghobakhloo et al., 2011; Anderson \& Swaminathan, 2011). In addition to other factors such as partner willingness and organizational culture. Factors that affect customer confidence and satisfaction and lead to increased reliance on e-commerce. The lack of attention to these factors in addition to other factors, the legal environment for electronic commerce is one of the most important obstacles to electronic commerce and a strong challenge to it. In the end, the adoption of e-commerce is a necessary requirement for the current era and the nature of customers and their environments with the need to focus on variables such as building customer confidence and approval of their satisfaction and quality of information and easy design for the user interface and the adoption of a global code for e-commerce ethics is one of the most important critical success factors that guide the organization to maintain the loyalty of electronic customers In an e-commerce environment.

\section{Acknowledgement}

The author would like to thank the respondents who participated in this research. she would also like to thank the Arab Open University on search support, Riyadh, Saudi Arabia.

\section{References}

Al-Tit, A. A. \& Nakhleh, H. (2014). The Role of E-Marketing in the Development of Internet User Attitudes toward Tourist Sites in Saudi Arabia. Journal of Administrative and Economic Sciences, 7(2), 25-44.

Al-Tit, A. A., Ben Dhaou, I., Albejaidi, F. M., \& Alshitawi, M. S. (2020). Traffic Safety Factors in the Qassim Region of Saudi Arabia. SAGE Open, 1-11. https://doi.org/10.1177/2158244020919500

Al-Tit, Ahmad \& Al-Ayed, Sura (2017). The Role of Knowledge Management in the Selection of Strategic Alternative to the Managers of Saudi's Telecommunication Companies. Arab Journal of Administration, 37(1), 21-38.

Al-Tit, Ahmad A. (2016). Management Information Systems in Public Institutions in Jordan: An Eye on Implementation Success Factors and their Relationship with Organizational Performance, International Journal of Advanced Computer Science and Applications, 7(7): 457-463. https://doi.org/10.14569/IJACSA.2016.070763

Anderson, R.E., \& Swaminathan, S. (2011). Customer satisfaction and loyalty in e-markets: A PLS path modeling approach. Journal of Marketing Theory and Practice, 19(2), 221-234.

Arshad, Y., Chin, W. P., Yahaya, S. N., Nizam, N. Z., Masrom, N. R., \& Ibrahim, S. N. S., (2018). Small and Medium Enterprises' Adoption for E-Commerce in Malaysia Tourism State. International Journal of Academic Research in Business and Social Sciences, 8(10), 1457-1557,

Awa, H. O., Ojiabo, O. U., \& Emecheta, B. C., (2015). Integrating TAM, TPB and TOE frameworks and expanding their characteristic constructs for e-commerce adoption by SMEs. Journal of Science \& Technology Policy Management, 6(1), 76-94,

Bhattacherjee, A. (2001). Understanding information systems continuance: An expectation-confirmation model. MIS Quarterly, 25(3), 351-370.

Chang, H. H., \& Chen, S. W. (2009). Consumer perception of interface quality, security, and loyalty in electronic commerce. Information \& Management. 46, 411-417.

Chiou, J.S. (2004). The antecedents of consumers' loyalty toward internet service providers. Information \& Management, 41(6), 685-695.

Cyr, D. (2008). Modeling web site design across cultures: relationships to trust, satisfaction, and e-loyalty. Journal of Management Information Systems, 24(4), 47-72.

Demangeot, C. \& Broderick, A. J. (2007). Conceptualising consumer behaviour in online shopping environments. International Journal of Retail \& Distribution Management, 35(11), 878-894.

Devaraj, S., Fan, M., \& Kohli, R. (2003). E-loyalty. Communications Of The ACM, 46(9), 184.

Dotan, T. (2002). How can e-business improve customer satisfaction? Case studies of the financial services industry. Journal of Information Technology Cases and Applications, 4(4), 22-49.

Eid, M., \& Al-Anazi, F. (2008). Factors Influencing Saudi Consumers Loyalty towards B2C E-commerce. 14th Americas Conference on Information Systems, Toronto, Ontario, Canada, August 14-17.

Eid. M. (2011). Determinant of E-commerce Customer Satisfaction, Trust, And Loyalty In Saudi Arabia. Journal of Electronic Commerce Research, 12(1). 
Ekanem, I., \& Abiade, G. E., (2018). Factors influencing the use of e-commerce by small enterprises in Nigeria. International Journal of ICT Research in Africa and the Middle East (IJICTRAME), 7(1), 37-53,

Fishbein, M., \& Ajzen, I. (1975). Belief, Attitude, Intention, and Behaviour: An Introduction to Theory and Research. Addison-Wesley.

Flavian, C., Guinaliu, M., \& Gurrea, R. (2006). The role played by perceived usability, satisfaction and consumer trust on website loyalty. Information and Management, 43(1), 1-14.

Friedman, B., Kahn, P. H., Jr., \& Howe, D. C. (2000). Trust Online. Communications of ACM, 43(12), 34-40.

Ghobakhloo, M., Arias-Aranda, D., \& Benitez-Amado, J., (2011). Adoption of e-commerce applications in SMEs. Industrial Management \& Data Systems, 111(8), 1238-1269,

Glanz, K., Rimer, B. K., \& Viswanath, K. (Eds.). (2015). Health behavior and health education: Theory, research, and practice (4th ed.). San Francisco: Jossey-Bass.

Guah, M.W. (2006). Conclusions. In: M.W. Guah and W.L. Currie, eds. Internet strategy: The road to web services solutions. Hershey, PA: IRM Press. 227-258.

Hussain, L. A., Baharudin, A. S., Jayaraman, K., \& Kiumarsi, S., (2019). B2B e-commerce technology factors with mediating effect perceived usefulness in Jordanian manufacturing SMES. Journal of Engineering Science and Technology, 14(1), 411-429,

Jiang, L., Jun, M. and Yang, Z. (2015). Customer-perceived value and loyalty: how do key service quality dimensions matter in the context of B2C e-commerce?. Service Business, 1-17, Online First Articles.

Kandampully, J., Zhang, T., \& Bilgihan, A. (2015). Customer loyalty: a review and future directions with a special focus on the hospitality industry. International Journal of Contemporary Hospitality Management, 27(3), 379-414.

Kassim, N. \& Abdullah, N.A. (2010). The effect of perceived service quality dimensions on customer satisfaction, trust, and loyalty in e-commerce settings: A cross cultural analysis. Asia Pacific Journal of Marketing and Logistics, 22(3), 351371.

Kassim, N. M., \& Ismail, S. (2009). Investigation the Complex Drivers of Loyalty in E-commerce Settings. Measuring Business Excellence, 13(1), 56-71.

Khatri, N., \& Ng, H.A. (2000). The role of intuition in strategic decision-making. Human Relations, 53, 57-86.

Kim, S., \& Lim, Y. (2001). Consumers' Perceived Importance of and Satisfaction with Internet Shopping. Electronic Markets, 11(3), 148-154.

Lin, H.H., \& Wang, Y.S. (2006). An examination of the determinants of consumer loyalty in mobile commerce context. Information \& Management, 43(3), 271-282.

McKnight, D.H., Choudhury, V., \& Kacmar, C. (2002). Developing and Validating Trust Measures for E-Commerce: An Integrative Typology. Information Systems Research, 13(3), 334-359.

Morgan, R. M., \& Hunt, S. D. (1994). The Commitment trust Theory of Relationship Marketing. Journal of Marketing, 58(July), 20-38.

Oliver, R. (1999). Whence customer loyalty?. Journal of Marketing, 63(1), 33-44.

Otieno, O., Liyala, S., Odongo, B., \& Abeka, S. (2016). Theory of Reasoned Action as an Underpinning to Technological Innovation Adoption Studies. World Journal of Computer Application and Technology, 4, 1-7.

Piha, L., \& Avlonitis, G. (2015). Customer defection in retail banking: attitudinal and behavioural consequences of failed service quality. Journal of Service Theory and Practice, 25(3), 304-326.

Porter, M. E. (2001). Competitive Strategy Creating and Sustaining Superior Performance, The Free Press U.S.A.

Ranaweera, C., \& Prabhu, J. (2003). The Influence of Satisfaction, Trust and Switching Barriers on Customer Retention in a Continuous Purchasing Setting. International Journal of Service Industry Management, 14(4), 374-95.

Rauyruen, P., \& Miller, K.E. (2007). Relationship quality as a predictor of B2B customer loyalty. Journal of Business Research. 60(1), 21-31.

Reichheld, F.F., \& Schefter, P. (2000). E-Loyalty: Your Secret Weapon on the Web. Harvard Business Review, 78, $105-113$.

Sambandam, R., \& Lord, K.R. (1995). Switching behaviour in automobile markets: a consideration-sets model, Journal of the Academy of Marketing Science, 23, 57-65.

Scupola, A. (2009). SMEs' e-commerce adoption: perspectives from Denmark and Australia. Journal of Enterprise Information Management, 22(1/2), 152-166.

Srinivasan, S.S., Anderson, R., \& Ponnavolu, K. (2002). Customer loyalty in e-commerce: an exploration of its antecedents and consequences. Journal of Retailing, 78, 41-50.

Wong, A., \& Zhou, L. (2006). Determinants and outcomes of relationship quality: a conceptual model and empirical investigation. Journal of International Consumer Marketing, 18(3), 81-105.

Zaied, A. N. H. (2012). Barriers to e-commerce adoption in Egyptian SMEs. International Journal of Information Engineering and Electronic Business, 4(3), 9-18.

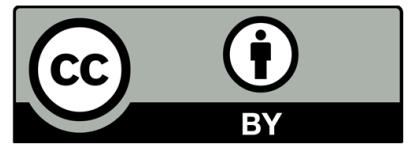

(C) 2022 by the authors; licensee Growing Science, Canada. This is an open access article distributed under the terms and conditions of the Creative Commons Attribution (CC-BY) license (http://creativecommons.org/licenses/by/4.0/). 